\title{
Vitamin D Status among Older Adults Residing in the Littoral and Andes Mountains in Ecuador
}

\author{
Carlos H. Orces \\ Department of Medicine, Laredo Medical Center, 1700 East Saunders, Laredo, TX 78041, USA \\ Correspondence should be addressed to Carlos H. Orces; corces07@yahoo.com
}

Received 14 March 2015; Accepted 15 July 2015

Academic Editor: George Panagiotis Chrousos

Copyright (C) 2015 Carlos H. Orces. This is an open access article distributed under the Creative Commons Attribution License, which permits unrestricted use, distribution, and reproduction in any medium, provided the original work is properly cited.

Objectives. To estimate the prevalence of 25-hydroxyvitamin D $(25(\mathrm{OH}) \mathrm{D})$ deficiency and its determinants among older adults in Ecuador. Methods. 25(OH)D deficiency and insufficiency prevalence rates were examined among participants in the National Survey of Health, Wellbeing, and Aging. Logistic regression models were used to evaluate demographic characteristics associated with 25(OH)D deficiency. Results. Of 2,374 participants with a mean age of $71.0(8.3)$ years, 25(OH)D insufficiency and deficiency were present in $67.8 \%$ (95\% CI, 65.3-70.2) and 21.6\% (95\% CI, 19.5-23.7) of older adults in Ecuador, respectively. Women (OR, 3.19; 95\% CI, 3.15-3.22), self-reported race as Indigenous (OR, 2.75; 95\% CI, 2.70-2.80), and residents in rural (OR, 4.49; 95\% CI, 4.40-4.58) and urban (OR, 2.74; 95\% CI, 2.69-2.80) areas of the Andes Mountains region were variables significantly associated with 25(OH)D deficiency among older adults. Conclusions. Despite abundant sunlight throughout the year in Ecuador, 25(OH)D deficiency was significantly prevalent among older women, Indigenous subjects, and subjects residing in the Andes Mountains region of the country. The present findings may assist public health authorities to implement policies of vitamin D supplementation among older adults at risk for this condition.

\section{Introduction}

25-Hydroxyvitamin D (25(OH)D) deficiency leads to alterations in calcium and phosphorus homeostasis, resulting in secondary hyperparathyroidism with increased bone turnover, progressive bone loss, and increased risk of fractures [1-4]. Moreover, recent studies have suggested an association between $25(\mathrm{OH}) \mathrm{D}$ deficiency and poor physical performance, increased risk of falls, and mortality among older adults [5-7].

Older adults are particularly at higher risk for $25(\mathrm{OH}) \mathrm{D}$ deficiency because sunlight exposure is usually limited as a result of lifestyle changes, such as clothing and decreased outdoor activities [8]. More importantly, the concentration of 7-dehydrocholesterol in the epidermis and the total production of previtamin $\mathrm{D}_{3}$ after exposure to solar ultraviolet $\mathrm{B}$ radiation decrease considerably among older adults [9].

A previous study of $25(\mathrm{OH}) \mathrm{D}$ status among six regions in the world reported that serum 25(OH)D levels below $75 \mathrm{nmol} / \mathrm{L}(30 \mathrm{ng} / \mathrm{mL})$ were prevalent in every region studied [10]. More recently, a systematic review of the prevalence of 25(OH)D deficiency in Latin America and the Caribbean concluded that $25(\mathrm{OH}) \mathrm{D}$ deficiency may be a public health problem in the region. However, the magnitude of the problem is currently unknown owing to limited number of studies in the general population [11]. In Ecuador, a small cross-sectional study conducted among older adults residing in a low income community in northwestern Quito $\left(00^{\circ} \mathrm{S}\right)$ reported that mean $25(\mathrm{OH}) \mathrm{D}$ levels were $19.0 \mathrm{ng} / \mathrm{mL}$ [12]. Despite this evidence, there is scarce information about $25(\mathrm{OH}) \mathrm{D}$ status among older Ecuadorians. Therefore, the present study aimed to estimate the prevalence of $25(\mathrm{OH}) \mathrm{D}$ deficiency and its determinants among older adults residing in the coastal and Andes Mountains regions of the country.

\section{Materials and Methods}

The present study was based on data from participants in the National Survey of Health, Wellbeing, and Aging (Encuesta 
de Salud, Bienestar y Envejecimiento) conducted in 2009. This survey is a probability sample of households with a least one person aged 60 years or older residing in the Andes Mountains and coastal regions of Ecuador. In the primary sampling stage, a total of 317 sectors from rural areas $(<2,000$ inhabitants) and 547 sectors from urban areas of the country were selected from the 2001 population Census cartography. In the secondary sampling stage, 18 households within each sector were randomly selected based on the assumption that at least one person aged 60 years or older lives in $24 \%$ and $23 \%$ of the households in the coastal and Andes Mountains regions, respectively. Between April and August 2010, a total of 2,375 participants in the SABE II survey underwent biochemical evaluation to determine their $25(\mathrm{OH}) \mathrm{D}$ status. Survey methodology, including operation manuals, is publicly available [13].

2.1. Characteristics of Subjects. Age and sex were selfreported. The race of participants was classified according to the following question: "Do you consider yourself to be White, Black, Mestizo, Mulatto, or Indigenous?” Body height in centimeters and weight in kilograms were measured and the body mass index was calculated $\left(\mathrm{Kg} / \mathrm{m}^{2}\right)$. Subjects were asked about their living status (alone versus accompanied), region (coasts versus mountains), and area of residence (urban versus rural). Literacy was defined by answering affirmatively to the question "Can you write and read a message?"

Alcohol consumption (none, 1 day, and $\geq 2$ days) was assessed by asking participants the following: "How many days per week on average have you drink alcohol for the past three months?" Smoking status was classified as current, former, and never. Subjects were considered to consume dairy product if they answered affirmatively to the question "Do you consume milk, cheese, or yogurt at least once per day?" Vigorous and regular physical activity was evaluated by the question, "Do you exercise such as jogging, dance, or perform rigorous physical activity at least three times weekly for the past year?" Participants who responded affirmatively were considered to engage in regular vigorous physical activity. Self-reported general health was grouped as excellent to good or fair to poor.

The following activities of daily living (ADLs) were included in the present study: walking across a room, dressing, bathing, eating, getting in and out of bed, and using the toilet. Those participants who needed help or were unable to perform one or more of the ADLs as a result of health problems were considered functionally impaired. Similarly, participants who reported difficulty walking a few city blocks or walking up a flight of stairs were considered to have mobility disability.

Serum $25(\mathrm{OH}) \mathrm{D}$ was measured by liquid chromatography at NetLab laboratory (Quito, Ecuador). The lowest limit of detection for the serum $25(\mathrm{OH}) \mathrm{D}$ assay was $4 \mathrm{ng} / \mathrm{mL}$. $25(\mathrm{OH}) \mathrm{D}$ status was classified as $<20 \mathrm{ng} / \mathrm{mL}$ and $<30 \mathrm{ng} / \mathrm{mL}$, which are cut-off values recommended by the Institute of Medicine and the Endocrine Society to define vitamin D deficiency and insufficiency, respectively $[14,15]$. One subject with a toxic $25(\mathrm{OH}) \mathrm{D}$ level $(>150 \mathrm{ng} / \mathrm{mL})$ was excluded from this analysis [3].

2.2. Statistical Analysis. ANOVA and $t$-tests for continuous variables and the chi-square test for categorical variables were used to compare mean $25(\mathrm{OH}) \mathrm{D}$ levels and the proportions of vitamin D deficiency and insufficiency, respectively. Logistic regression models adjusted for age, sex, and body mass index were created to examine the independent associations between sociodemographic, behavior, and health characteristics of the participants and $25(\mathrm{OH}) \mathrm{D}$ deficiency. Results of the multivariate model are presented as odds ratios (OR) with their 95\% confidence intervals (95\% CI). To examine the geographic distribution of $25(\mathrm{OH}) \mathrm{D}$ deficiency in Ecuador, the proportion of $25(\mathrm{OH}) \mathrm{D}$ deficiency by provinces of the coastal and Andes Mountains regions of the country was age-adjusted by the direct method using the 2010 Census population of Ecuador as the standard [16]. All analyses used sample weights to account for the complex survey design. Statistical analyses were performed using SPSS, version 17 software (SPSS Inc., Chicago, IL).

\section{Results}

A total of 2,374 participants with a mean age of 71.0 (8.3) years had $25(\mathrm{OH}) \mathrm{D}$ measured. Table 1 shows the characteristics of participants and their mean $25(\mathrm{OH}) \mathrm{D}$ levels. In general, $25(\mathrm{OH}) \mathrm{D}$ levels decreased with advancing age and were lower among women. By race, 25(OH)D levels were significantly lower among Indigenous as compared to other ethnic groups. Moreover, participants who engaged in regular vigorous physical activity and consumed dairy products had higher $25(\mathrm{OH}) \mathrm{D}$ levels than those who did not. On the contrary, lower $25(\mathrm{OH})$ levels were seen among subjects who never smoked or drink alcohol, and subjects with self-reported mobility and ADLs limitations.

Overall, 67.8\% (95\% CI, 65.3-70.2) of participants had 25(OH)D levels below $30 \mathrm{ng} / \mathrm{mL}$ and $21.6 \%$ (95\% CI, 19.523.7) had levels below $20 \mathrm{ng} / \mathrm{mL}$, representing an estimated 808,000 and 256,000 older Ecuadorians with 25(OH)D insufficiency and deficiency, respectively. Table 2 shows the prevalence of $25(\mathrm{OH}) \mathrm{D}$ deficiency and insufficiency according to certain characteristics of the survey participants. In general, $25(\mathrm{OH}) \mathrm{D}$ deficiency and insufficiency were considerably higher among the elderly, women, Indigenous subjects, obese subjects, and residents in rural and urban areas of the Andes Mountains.

As shown in Figure 1, the age-adjusted prevalence of $25(\mathrm{OH}) \mathrm{D}$ deficiency among older adults varied across the country. However, residents in provinces located in the Andes Mountains region had consistently higher $25(\mathrm{OH}) \mathrm{D}$ deficiency prevalence rates than those residing in provinces along the coastal region. For instance, up to $62.0 \%$ and $53.8 \%$ of residents in the provinces of Bolivar and Chimborazo were considered deficient in $25(\mathrm{OH}) \mathrm{D}$. Conversely, low prevalence of $25(\mathrm{OH}) \mathrm{D}$ deficiency ranging from $8.3 \%$ to $17.8 \%$ was found among subjects residing in provinces of the coastal region. 
TABLE 1: 25(OH)D levels by selected characteristics among older adults in Ecuador.

\begin{tabular}{|c|c|c|c|}
\hline & Subjects (\%) & $25(\mathrm{OH}) \mathrm{D}$ levels $(\mathrm{SD})$ & $P$ value \\
\hline \multicolumn{4}{|l|}{ Age groups, yrs. } \\
\hline $60-69$ & $1,158(51.7)$ & $27.6(11.5)$ & \multirow{3}{*}{$<0.001$} \\
\hline $70-79$ & $724(31.4)$ & $25.5(9.7)$ & \\
\hline$\geq 80$ & $403(16.8)$ & $25.9(13.2)$ & \\
\hline \multicolumn{4}{|l|}{ Sex } \\
\hline Men & $1,072(44.5)$ & $30.0(12.3)$ & \multirow{2}{*}{$<0.001$} \\
\hline Women & $1,302(55.5)$ & $23.8(9.4)$ & \\
\hline \multicolumn{4}{|l|}{ Race } \\
\hline Indian & $207(10.7)$ & $21.6(8.8)$ & \multirow{5}{*}{$<0.001$} \\
\hline Black & $80(3.6)$ & $27.7(12.4)$ & \\
\hline Mestizo & $1,584(69.8)$ & $26.9(10.6)$ & \\
\hline Mulatto & $84(3.5)$ & $26.4(8.4)$ & \\
\hline White & $273(12.5)$ & $26.7(12.3)$ & \\
\hline \multicolumn{4}{|l|}{$\operatorname{BMI}\left(\mathrm{Kg} / \mathrm{m}^{2}\right)$} \\
\hline Underweight & $63(2.3)$ & $26.6(11.6)$ & \multirow{4}{*}{$<0.001$} \\
\hline Normal & $920(41.9)$ & $28.0(12.3)$ & \\
\hline Overweight & $877(37.7)$ & $26.1(10.1)$ & \\
\hline Obese & $408(18.1)$ & $24.9(10.7)$ & \\
\hline \multicolumn{4}{|l|}{ Living alone } \\
\hline Yes & $209(9.1)$ & $27.1(13.1)$ & \multirow{2}{*}{$<0.001$} \\
\hline No & $2,165(90.5)$ & $26.5(11.0)$ & \\
\hline \multicolumn{4}{|l|}{ Area of residence } \\
\hline Rural mountains & $505(20.4)$ & $21.7(8.0)$ & \multirow{4}{*}{$<0.001$} \\
\hline Urban mountains & $685(29.7)$ & $22.8(6.2)$ & \\
\hline Rural coast & $505(13.1)$ & $32.6(14.1)$ & \\
\hline Urban coast & $877(36.8)$ & $30.0(12.5)$ & \\
\hline \multicolumn{4}{|l|}{ Literacy } \\
\hline Yes & $1,664(69.4)$ & $27.1(10.8)$ & \multirow{2}{*}{$<0.001$} \\
\hline No & 707 (30.6) & $25.2(12.1)$ & \\
\hline \multicolumn{4}{|c|}{ Consume dairy products } \\
\hline Yes & $1,586(66.8)$ & $27.0(11.9)$ & \multirow{2}{*}{$<0.001$} \\
\hline No & $788(33.2)$ & $25.5(9.7)$ & \\
\hline \multicolumn{4}{|l|}{ Smoking status } \\
\hline Current & $243(10.3)$ & $28.9(9.8)$ & \multirow{3}{*}{$<0.001$} \\
\hline Former & $661(27.9)$ & $29.6(13.1)$ & \\
\hline Never & $1,464(61.8)$ & $24.6(10.1)$ & \\
\hline \multicolumn{4}{|l|}{ Alcohol use } \\
\hline None & $1,891(77.9)$ & $26.0(11.0)$ & \multirow{3}{*}{$<0.001$} \\
\hline 1 day & $420(19.4)$ & $27.8(11.6)$ & \\
\hline$\geq 2$ days & $60(2.7)$ & $31.7(12.6)$ & \\
\hline \multicolumn{4}{|l|}{ Physical activity } \\
\hline Yes & $747(32.9)$ & $27.7(11.4)$ & $<0.001$ \\
\hline No & $1,626(67.1)$ & $26.0(11.1)$ & \\
\hline Self-reported health & & & \\
\hline Excellent to good & $557(24.6)$ & $26.3(11.0)$ & $<0.001$ \\
\hline Fair to poor & $1,812(75.4)$ & $26.6(11.3)$ & $<0.001$ \\
\hline Mobility disability & & & \\
\hline Yes & $990(41.4)$ & $25.5(10.4)$ & $<0.001$ \\
\hline No & $1,384(58.6)$ & $27.2(11.7)$ & \\
\hline Limitation in ADLs & & & \\
\hline Yes & $652(26.5)$ & 25.9 (11.9) & $<0.001$ \\
\hline No & $1,719(73.5)$ & $26.7(11.0)$ & $<0.001$ \\
\hline
\end{tabular}


TAble 2: Prevalence of 25(OH)D deficiency and insufficiency among older adults in Ecuador.

\begin{tabular}{|c|c|c|c|c|}
\hline & $\begin{array}{c}25(\mathrm{OH}) \mathrm{D}<20 \mathrm{ng} / \mathrm{mL} \\
\%(95 \% \mathrm{CI}) \\
\end{array}$ & $P$ value & $\begin{array}{c}25(\mathrm{OH}) \mathrm{D}<30 \mathrm{ng} / \mathrm{mL} \\
\%(95 \% \mathrm{CI})\end{array}$ & $P$ value \\
\hline \multicolumn{5}{|l|}{ Age groups, yrs. } \\
\hline $60-69$ & $18.2(15.6-21.1)$ & \multirow{3}{*}{$<0.001$} & $64.8(61.2-68.3)$ & \multirow{3}{*}{$<0.001$} \\
\hline $70-79$ & $22.4(18.9-26.3)$ & & $70.5(66.1-74.6)$ & \\
\hline$\geq 80$ & $28.5(22.7-35.0)$ & & $68.7(62.4-74.5)$ & \\
\hline \multicolumn{5}{|l|}{ Sex } \\
\hline Men & $11.5(9.4-13.9)$ & \multirow{2}{*}{$<0.001$} & $55.9(52.1-59.7)$ & \multirow{2}{*}{$<0.001$} \\
\hline Women & $29.6(26.5-32.9)$ & & $77.4(74.2-80.2)$ & \\
\hline \multicolumn{5}{|l|}{ Race } \\
\hline Indian & $40.5(31.3-50.4)$ & \multirow{5}{*}{$<0.001$} & $84.0(76.2-89.6)$ & \multirow{5}{*}{$<0.001$} \\
\hline Mestizo & $19.2(17.1-21.6)$ & & $65.8(62.7-68.8)$ & \\
\hline Black & $16.0(9.2-26.4)$ & & $63.0(49.7-74.5)$ & \\
\hline Mulatto & $15.3(8.0-27.1)$ & & $69.4(54.7-80.9)$ & \\
\hline White & $22.5(17.1-29.1)$ & & $67.9(60.6-74.3)$ & \\
\hline \multicolumn{5}{|l|}{$\mathrm{BMI}\left(\mathrm{Kg} / \mathrm{m}^{2}\right)$} \\
\hline Underweight & $20.4(11.1-34.5)$ & \multirow{4}{*}{$<0.001$} & $65.9(49.9-79.0)$ & \multirow{4}{*}{$<0.001$} \\
\hline Normal & $19.3(16.3-22.8)$ & & $61.6(57.3-65.7)$ & \\
\hline Overweight & $19.2(16.3-22.6)$ & & $71.1(67.4-74.6)$ & \\
\hline Obesity & $28.3(23.3-33.9)$ & & $74.0(68.1-79.2)$ & \\
\hline \multicolumn{5}{|l|}{ Living status } \\
\hline Alone & $20.9(15.3-27.8)$ & \multirow{2}{*}{$<0.001$} & $69.1(60.0-77.0)$ & \multirow{2}{*}{$<0.001$} \\
\hline Accompanied & $21.6(19.5-23.9)$ & & $67.7(65.1-70.2)$ & \\
\hline \multicolumn{5}{|l|}{ Area of residence } \\
\hline Rural mountains & $34.8(29.3-40.8)$ & \multirow{4}{*}{$<0.001$} & $86.6(82.5-89.9)$ & \multirow{4}{*}{$<0.001$} \\
\hline Urban mountains & $26.6(22.8-30.8)$ & & $86.2(82.5-89.2)$ & \\
\hline Rural coast & $10.6(7.1-15.6)$ & & $44.3(37.4-51.5)$ & \\
\hline Urban coast & $14.0(11.6-16.9)$ & & $50.9(46.7-55.2)$ & \\
\hline \multicolumn{5}{|l|}{ Literacy } \\
\hline Yes & $19.2(17.0-21.5)$ & \multirow{2}{*}{$<0.001$} & $65.7(62.7-68.5)$ & \multirow{2}{*}{$<0.001$} \\
\hline No & $27.1(22.8-31.8)$ & & $73.2(68.7-77.2)$ & \\
\hline \multicolumn{5}{|c|}{ Consume dairy products } \\
\hline Yes & $21.0(18.6-23.6)$ & \multirow{2}{*}{$<0.001$} & $66.9(63.9-69.8)$ & $<0.001$ \\
\hline No & $22.8(19.0-27.0)$ & & $69.7(65.1-73.8)$ & \\
\hline Smoking status & & & & \\
\hline Current & $13.5(8.6-20.6)$ & & $54.3(46.0-62.4)$ & \\
\hline Former & $14.3(11.3-17.8)$ & $<0.001$ & $57.7(52.8-62.4)$ & $<0.001$ \\
\hline Never & $26.4(23.6-29.4)$ & & $75.0(72.0-77.8)$ & \\
\hline Alcohol use & & & & \\
\hline None & $22.8(20.5-25.4)$ & & $68.8(66.0-71.4)$ & \\
\hline 1 day & $17.9(13.7-23.0)$ & $<0.001$ & $66.2(60.2-71.8)$ & $<0.001$ \\
\hline$\geq 2$ days & $11.3(4.8-24.3)$ & & $51.7(34.8-68.2)$ & \\
\hline Physical activity & & & & \\
\hline Yes & $18.8(15.6-22.5)$ & $<0.001$ & $65.5(60.8-69.9)$ & $<0.001$ \\
\hline No & $22.9(20.4-25.6)$ & $<0.001$ & $69.0(66.0-71.8)$ & \\
\hline Self-reported health & & & & \\
\hline Excellent to good & $22.5(18.6-27.0)$ & $<0.001$ & $70.6(65.9-74.9)$ & $<0.001$ \\
\hline Fair to poor & $21.1(18.8-23.6)$ & $<0.001$ & $66.8(63.9-69.6)$ & $<0.001$ \\
\hline
\end{tabular}


TABLE 2: Continued.

\begin{tabular}{|c|c|c|c|c|}
\hline & $\begin{array}{c}25(\mathrm{OH}) \mathrm{D}<20 \mathrm{ng} / \mathrm{mL} \\
\%(95 \% \mathrm{CI})\end{array}$ & $P$ value & $\begin{array}{c}25(\mathrm{OH}) \mathrm{D}<30 \mathrm{ng} / \mathrm{mL} \\
\%(95 \% \mathrm{CI})\end{array}$ & $P$ value \\
\hline \multicolumn{5}{|c|}{ Mobility disability } \\
\hline Yes & $22.9(19.6-26.4)$ & \multirow{2}{*}{$<0.001$} & $69.8(65.9-73.5)$ & \multirow{2}{*}{$<0.001$} \\
\hline No & $20.6(18.1-23.4)$ & & $66.4(63.1-69.5)$ & \\
\hline \multicolumn{5}{|c|}{ Limitation in ADLs } \\
\hline Yes & $25.4(21.2-30.0)$ & \multirow{2}{*}{$<0.001$} & $67.1(62.1-71.6)$ & \multirow[t]{2}{*}{$<0.001$} \\
\hline No & $20.2(17.9-22.7)$ & & $68.1(65.2-70.9)$ & \\
\hline
\end{tabular}
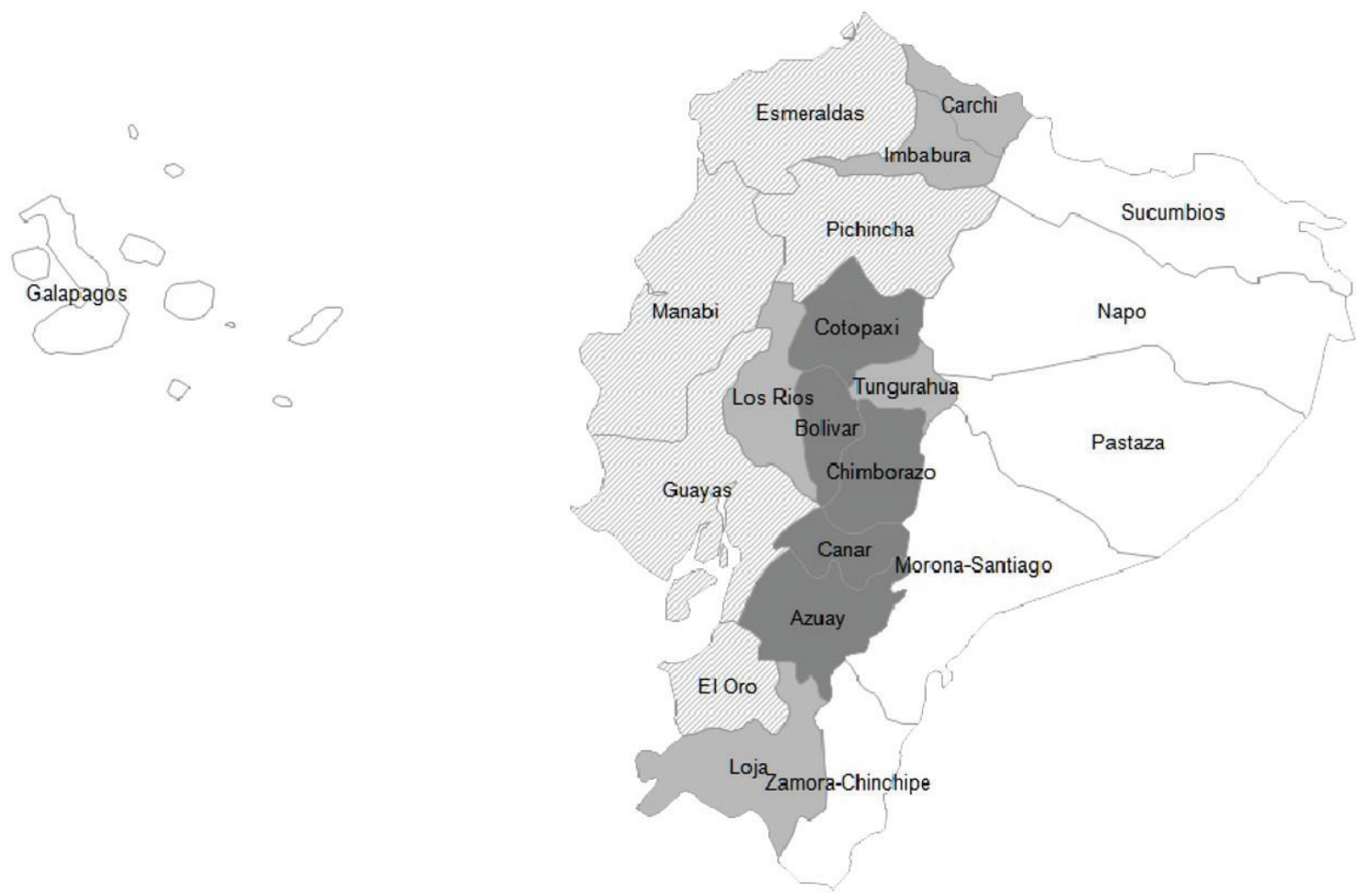

FIGURE 1: Prevalence of vitamin D deficiency among older adults in Ecuador.

As shown in Table 3, the results of the multivariate logistic regression model indicate that women (OR, 3.19; 95\% CI, 3.15-3.22), self-reported race as Indigenous (OR, 2.75; 95\% $\mathrm{CI}, 2.70-2.80)$, and subjects residing in rural (OR, 4.49; 95\% CI, 4.40-4.58) and urban (OR, 2.74; 95\% CI, 2.69-2.80) areas of the Andes Mountains region were variables strongly and independently associated with 25(OH)D deficiency among older adults in Ecuador.

\section{Discussion}

The present study indicates that $25(\mathrm{OH}) \mathrm{D}$ deficiency and insufficiency were present in $21.6 \%$ and $67.8 \%$ of older adults in Ecuador, respectively. Moreover, the prevalence of $25(\mathrm{OH}) \mathrm{D}$ deficiency was particularly common among women, Indigenous subjects, and residents in the Andes Mountains region of the country.
Compared with studies of $25(\mathrm{OH}) \mathrm{D}$ status among postmenopausal women in Latin America, the prevalence of $25(\mathrm{OH}) \mathrm{D}$ deficiency reported among women in Santiago $\left(33^{\circ} \mathrm{S}\right)$, Chile, was higher than that found among women in Ecuador [17]. Similarly, a study of ambulatory adults aged 65 years or older in seven cities from Argentina demonstrated that the prevalence of $25(\mathrm{OH}) \mathrm{D}$ deficiency varied from $73 \%$ in the southern cities $\left(41^{\circ}\right.$ to $\left.55^{\circ} \mathrm{S}\right)$ to $50 \%$ in the northern cities $\left(26^{\circ} \mathrm{S}\right.$ to $\left.27^{\circ} \mathrm{S}\right)$ [18]. On the contrary, the prevalence of $25(\mathrm{OH}) \mathrm{D}$ deficiency among women with osteopenia and osteoporosis across six cities in Brazil was lower than that found among Ecuadorian women [19]. It is of interest that, among postmenopausal Brazilian women, an inverse correlation was found between the mean serum $25(\mathrm{OH}) \mathrm{D}$ level site and latitude with a mean reduction of $0.28 \mathrm{ng} / \mathrm{mL}$ for each latitude's degree south of the equatorial line. Despite these findings, only $10 \%$ of postmenopausal women from the most 
TABLE 3: Associations between characteristics of participants and 25(OH)D deficiency.

\begin{tabular}{|c|c|c|}
\hline & Crude OR (95\% CI) & Adjusted OR (95\% CI) \\
\hline \multicolumn{3}{|l|}{ Age groups, yrs. } \\
\hline $60-69$ & 1.00 & 1.00 \\
\hline $70-79$ & $1.30(1.28-1.31)$ & $1.31(1.30-1.33)$ \\
\hline$\geq 80$ & $1.79(1.77-1.81)$ & $1.54(1.52-1.56)$ \\
\hline \multicolumn{3}{|l|}{ Sex } \\
\hline Men & 1.00 & 1.00 \\
\hline Women & $3.25(3.21-3.28)$ & $3.19(3.15-3.22)$ \\
\hline \multicolumn{3}{|l|}{$\operatorname{BMI}\left(\mathrm{Kg} / \mathrm{m}^{2}\right)$} \\
\hline Underweight & 1.00 & 1.00 \\
\hline Normal & $0.93(0.90-0.96)$ & $0.99(0.95-1.02)$ \\
\hline Overweight & $0.92(0.89-0.95)$ & $0.92(0.89-0.95)$ \\
\hline Obesity & $1.53(1.48-1.58)$ & $1.30(1.25-1.34)$ \\
\hline \multicolumn{3}{|l|}{ Race } \\
\hline Indigenous & $2.34(2.30-2.38)$ & $2.75(2.70-2.80)$ \\
\hline Black & $0.65(0.63-0.67)$ & $0.75(0.85-0.88)$ \\
\hline Mestizo & $0.81(0.80-0.83)$ & $0.89(0.88-0.91)$ \\
\hline Mulatto & $0.62(0.60-0.63)$ & $0.71(0.68-0.73)$ \\
\hline White & 1.00 & 1.00 \\
\hline \multicolumn{3}{|l|}{ Area of residence } \\
\hline Rural mountains & $4.51(4.43-4.59)$ & $4.49(4.40-4.58)$ \\
\hline Urban mountains & $3.05(3.00-3.11)$ & $2.74(2.69-2.80)$ \\
\hline Urban coast & $1.37(1.35-1.40)$ & $1.22(1.20-1.25)$ \\
\hline Rural coast & 1.00 & 1.00 \\
\hline \multicolumn{3}{|l|}{ Living status } \\
\hline Alone & $1.04(1.03-1.06)$ & $1.00(0.98-1.01)$ \\
\hline Accompanied & 1.00 & 1.00 \\
\hline \multicolumn{3}{|l|}{ Literacy } \\
\hline Yes & 1.00 & 1.00 \\
\hline No & $1.56(1.54-1.57)$ & $1.16(1.15-1.17)$ \\
\hline \multicolumn{3}{|c|}{ Consume dairy products } \\
\hline Yes & 1.00 & 1.00 \\
\hline No & $1.10(1.09-1.11)$ & $1.14(1.13-1.15)$ \\
\hline \multicolumn{3}{|l|}{ Smoking status } \\
\hline Current & $0.43(0.42-0.44)$ & $0.97(0.95-0.99)$ \\
\hline Former & $0.46(0.45-0.46)$ & $0.88(0.87-0.89)$ \\
\hline Never & 1.00 & 1.00 \\
\hline \multicolumn{3}{|l|}{ Alcohol use } \\
\hline None & 1.00 & 1.00 \\
\hline 1 day & $0.73(0.72-0.74)$ & $1.20(1.18-1.22)$ \\
\hline$\geq 2$ days & $0.43(0.41-0.44)$ & $0.87(0.84-0.91)$ \\
\hline \multicolumn{3}{|l|}{ Physical activity } \\
\hline Yes & 1.00 & 1.00 \\
\hline No & $0.78(0.77-0.78)$ & $1.15(1.13-1.16)$ \\
\hline \multicolumn{3}{|l|}{ Self-reported health } \\
\hline Excellent to good & 1.00 & 1.00 \\
\hline Fair to poor & $0.92(0.91-0.92)$ & $0.73(0.72-0.74)$ \\
\hline \multicolumn{3}{|l|}{ Mobility disability } \\
\hline Yes & $1.13(1.12-1.14)$ & $0.75(0.74-0.76)$ \\
\hline No & 1.00 & 1.00 \\
\hline \multicolumn{3}{|l|}{ Limitations in ADLs } \\
\hline Yes & $1.34(1.33-1.35)$ & $1.01(1.00-1.02)$ \\
\hline No & 1.00 & 1.00 \\
\hline
\end{tabular}


northern city of Recife, Brazil $\left(8^{\circ} \mathrm{S}\right)$, had evidence of 25(OH)D deficiency [19].

Although there is scarce data about 25(OH)D status among older men in Latin America, the prevalence of 25(OH)D deficiency among older men in Ecuador was lower than that reported among older men in Recife $\left(8^{\circ} \mathrm{S}\right)$, Brazil, and subjects who participated in the Osteoporotic Fractures in Men Study [20, 21].

It is of relevance that a high prevalence of $25(\mathrm{OH}) \mathrm{D}$ deficiency was found among participants who self-reported their race as Indigenous. Although Indigenous people accounted for only 7.0\% of the population in Ecuador in 2010, 25(OH)D deficiency was present in up to $40.5 \%$ of older adults from this ethnic group [16]. In fact, after adjustment for age, sex, and $\mathrm{BMI}$, the prevalence of $25(\mathrm{OH}) \mathrm{D}$ deficiency was 2.7 -fold higher among older Indigenous subjects as compared with Whites. According to results from the National Census 2010, the Indigenous population is predominantly concentrated in certain provinces of the Andes Mountains region such as Chimborazo, Cotopaxi, Imbabura, and Bolivar [16]. It is of relevance that higher prevalence rates of $25(\mathrm{OH}) \mathrm{D}$ deficiency were also found among older residents in these provinces.

Despite of abundant sunlight exposure in the country, it is conceivable that the combination of dark skin pigmentation, clouds cover, and wearing wool ponchos to protect from cold climates at high altitude may be an effective barrier to ultraviolet $\mathrm{B}$ radiation and account for the high prevalence of 25(OH)D deficiency observed among older Indigenous people in Ecuador. Previous studies have shown a high prevalence of $25(\mathrm{OH}) \mathrm{D}$ deficiency and insufficiency in young healthy Jordanian women and ultra-Orthodox men in Israel, whose dress-code precludes sunlight exposure [22, 23]. Likewise, consistent with the present findings, a recent investigation reported a high prevalence of $25(\mathrm{OH}) \mathrm{D}$ deficiency and insufficiency among Indigenous children living at high altitudes in San Antonio de Los Cobres (24. $\mathrm{S}$ ), Argentina [24].

It is of interest that older Blacks had the lowest prevalence of 25(OH)D deficiency in Ecuador. This finding may be partly explained by the fact that $72.7 \%$ of subjects from this racial group reside in the coastal region characterized by warm climates and abundant sunlight exposure throughout the year [16]. Therefore, it is feasible that older Blacks devote more time to outdoor physical activities resulting in prolonged exposure to ultraviolet $\mathrm{B}$ radiation. For instance, the province of Esmeraldas has the highest proportion of Blacks in the country. Conversely, this province had the lowest ageadjusted prevalence of $25(\mathrm{OH}) \mathrm{D}$ deficiency among older adults in the country. These results contrast with those from previous studies, which have consistently reported higher prevalence rates of $25(\mathrm{OH}) \mathrm{D}$ deficiency among Blacks [25, 26].

The prevalence of $25(\mathrm{OH}) \mathrm{D}$ deficiency among older Ecuadorians varied considerably among regions and areas of the country. However, subjects residing in rural and urban areas of the Andes Mountains had 4.4- and 2.7-fold higher rates of $25(\mathrm{OH}) \mathrm{D}$ deficiency as compared with residents in rural areas of the coastal region, respectively. This marked geographic disparity in the prevalence of $25(\mathrm{OH}) \mathrm{D}$ deficiency among older Ecuadorians deserves attention and should be further investigated. However, it may be partly explained by skin phenotype, limited outdoor activities, and cultural clothing as a result of cool temperatures among subjects living in the Andes Mountains region of the country. Moreover, at similar latitudes, higher prevalence rates of $25(\mathrm{OH}) \mathrm{D}$ deficiency were found among subjects residing in the Andes Mountains region. For instance, the age-adjusted prevalence of 25(OH)D deficiency in the Andes Mountains province of Carchi $\left(2^{\circ} 2^{\prime} \mathrm{N}\right)$ was $20.4 \%$. On the contrary, the prevalence of 25(OH)D deficiency in the coastal province of Esmeraldas $\left(0^{\circ} 58^{\prime} \mathrm{S}\right)$ was only $8.3 \%$.

Older Ecuadorians who engaged in regular vigorous physical activity had higher levels of $25(\mathrm{OH}) \mathrm{D}$ as compared to those who did not. Similarly, Scragg and Camargo Jr. reported a significant relationship between the frequency of regular outdoor physical activity and higher levels of $25(\mathrm{OH}) \mathrm{D}$. It is of interest that the authors also found similar $25(\mathrm{OH}) \mathrm{D}$ levels between subjects aged $20-39$ and 60 or more years who engaged frequently in outdoors activities [27]. Moreover, a recent analysis of the Longitudinal Aging Study Amsterdam demonstrated that outdoor physical activity with a high intensity, such as gardening and cycling, was associated with higher 25(OH)D levels [28]. Maintaining an adequate $25(\mathrm{OH}) \mathrm{D}$ status is a major public health task because low $25(\mathrm{OH}) \mathrm{D}$ concentrations among older adults have been associated with poor muscle strength, worse physical performance measures, disability, hip fractures, and mortality $[5,29,30]$.

Several limitations should be mentioned in interpreting the present results. First, participants self-reported their characteristics, which may be a source of recall bias. Second, dietary intake of vitamin D or use of vitamin D supplements was not assessed in the survey. Third, the laboratory did not report the 25(OH)D intra- and interassay coefficient of variation. Fourth, these results may be generalized to older adults residing in the coastal and Andes Mountains regions of the country. However, older adults from the Amazon region and the Galapagos Islands represent only 3.3\% of the population aged 60 years or older in Ecuador [31]. Despite these limitations, the present study is the first to report the prevalence of 25(OH)D deficiency among older Ecuadorians.

In conclusion, despite abundant sunlight throughout the year in Ecuador, 25(OH)D deficiency was significantly prevalent among older women, Indigenous subjects, and residents in the Andes Mountains region of the country. The present findings may assist public health authorities to implement policies of vitamin D supplementation, particularly among older adults at risk for this condition.

\section{Conflict of Interests}

The author declares that there is no conflict of interests regarding the publication of this paper.

\section{References}

[1] P. Lips, "Vitamin D deficiency and secondary hyperparathyroidism in the elderly: consequences for bone loss and fractures 
and therapeutic implications," Endocrine Reviews, vol. 22, no. 4, pp. 477-501, 2001.

[2] C. De Cock, O. Bruyere, J. Collette, and J.-Y. Reginster, "Vitamin D inadequacy in French osteoporotic and osteopenic women," Joint Bone Spine, vol. 75, no. 5, pp. 567-572, 2008.

[3] M. F. Holick, "Medical progress: vitamin D deficiency," The New England Journal of Medicine, vol. 357, no. 3, pp. 266-281, 2007.

[4] M. F. Holick, E. S. Siris, N. Binkley et al., "Prevalence of vitamin D inadequacy among postmenopausal North American women receiving osteoporosis therapy," The Journal of Clinical Endocrinology \& Metabolism, vol. 90, no. 6, pp. 3215-3224, 2005.

[5] V. Hirani, R. G. Cumming, V. Naganathan et al., "Associations between serum 25-hydroxyvitamin $\mathrm{D}$ concentrations and multiple health conditions, physical performance measures, disability, and all-cause mortality: the concord health and ageing in men project," Journal of the American Geriatrics Society, vol. 62, no. 3, pp. 417-425, 2014.

[6] D. Rothenbacher, J. Klenk, M. D. Denkinger et al., "Prospective evaluation of renal function, serum vitamin D level, and risk of fall and fracture in community-dwelling elderly subjects," Osteoporosis International, vol. 24, no. 3, pp. 923-932, 2014.

[7] R. Chowdhury, S. Kunutsor, A. Vitezova et al., "Vitamin D and risk of cause specific death: systematic review and meta-analysis of observational cohort and randomised intervention studies," British Medical Journal, vol. 348, Article ID g1903, 2014.

[8] A. Hossein-Nezhad and M. F. Holick, "Vitamin D for health: a global perspective," Mayo Clinic Proceedings, vol. 88, no. 7, pp. 720-755, 2013.

[9] J. MacLaughlin and M. F. Holick, "Aging decreases the capacity of human skin to produce vitamin D3," Journal of Clinical Investigation, vol. 76, no. 4, pp. 1536-1538, 1985.

[10] A. Mithal, D. A. Wahl, J. Bonjour et al., "Global vitamin D status and determinants of hypovitaminosis D," Osteoporosis International, vol. 20, no. 11, pp. 1807-1820, 2009.

[11] A. Brito, H. Cori, M. Olivares, M. F. Mujica, G. Cediel, and D. L. De Romaña, "Less than adequate vitamin D status and intake in Latin America and the Caribbean: a problem of unknown magnitude," Food and Nutrition Bulletin, vol. 34, no. 1, pp. 5264, 2013.

[12] F. Sempértegui, B. Estrella, N. Elmieh et al., "Nutritional, immunological and health status of the elderly population living in poor neighbourhoods of Quito, Ecuador," British Journal of Nutrition, vol. 96, no. 5, pp. 845-853, 2006.

[13] 2014, http://www.ecuadorencifras.gob.ec/encuesta-de-saludbienestar-del-adulto-mayor/.

[14] Institute of Medicine, Dietary Reference Intakes for Calcium and Vitamin D, National Academies Press, Washington, DC, USA, 2010.

[15] M. F. Holick, N. C. Binkley, H. A. Bischoff-Ferrari et al., "Evaluation, treatment, and prevention of vitamin D deficiency: an endocrine society clinical practice guideline," Journal of Clinical Endocrinology and Metabolism, vol. 96, no. 7, pp. 19111930, 2011.

[16] April 2014, http://anda.inec.gob.ec/anda/index.php/catalog/ 292/download/5317.

[17] G. González, J. N. Alvarado, A. Rojas, C. Navarrete, C. G. Velásquez, and E. Arteaga, "High prevalence of vitamin D deficiency in Chilean healthy postmenopausal women with normal sun exposure: additional evidence for a worldwide concern," Menopause, vol. 14, no. 3, pp. 455-461, 2007.
[18] B. Oliveri, L. Plantalech, A. Bagur et al., "High prevalence of vitamins D insufficiency in healthy elderly people living at home in Argentina," European Journal of Clinical Nutrition, vol. 58, no. 2, pp. 337-342, 2004.

[19] H. P. Arantes, C. A. M. Kulak, C. E. Fernandes et al., "Correlation between 25-hydroxyvitamin D levels and latitude in Brazilian postmenopausal women: from the Arzoxifene Generations Trial," Osteoporosis International, vol. 24, no. 10, pp. 2707-2712, 2013.

[20] M. A. Cabral, C. N. Borges, J. M. C. Maia, C. A. M. Aires, and F. Bandeira, "Prevalence of vitamin D deficiency during the summer and its relationship with sun exposure and skin phototype in elderly men living in the tropics," Clinical Interventions in Aging, vol. 8, pp. 1347-1351, 2013.

[21] E. Orwoll, C. M. Nielson, L. M. Marshall et al., "Vitamin D deficiency in older men," The Journal of Clinical Endocrinology \& Metabolism, vol. 94, no. 4, pp. 1214-1222, 2009.

[22] A. A. Mishal, "Effects of different dress styles on vitamin D levels in healthy young Jordanian women," Osteoporosis International, vol. 12, no. 11, pp. 931-935, 2001.

[23] A. Tsur, M. Metzger, and R. Dresner-Pollak, "Effect of different dress style on vitamin D level in healthy young Orthodox and ultra-Orthodox students in Israel," Osteoporosis International, vol. 22, no. 11, pp. 2895-2898, 2011.

[24] V. Hirschler, G. Maccallini, C. Molinari et al., "Low vitamin D concentrations among indigenous Argentinean children living at high altitudes," Pediatric Diabetes, vol. 14, no. 3, pp. 203-210, 2013.

[25] S. S. Harris, E. Soteriades, J. A. S. Coolidge, S. Mudgal, and B. Dawson-Hughes, "Vitamin D insufficiency and hyperparathyroidism in a low income, multiracial, elderly population," Journal of Clinical Endocrinology and Metabolism, vol. 85, no. 11, pp. 4125-4130, 2000.

[26] M. K. Shea, D. K. Houston, J. A. Tooze et al., "Correlates and prevalence of insufficient 25-hydroxyvitamin D status in black and white older adults: the health, aging and body composition study," Journal of the American Geriatrics Society, vol. 59, no. 7, pp. 1165-1174, 2011.

[27] R. Scragg and C. A. Camargo Jr., "Frequency of leisure-time physical activity and serum 25-hydroxyvitamin D levels in the US population: results from the third national health and nutrition examination survey," The American Journal of Epidemiology, vol. 168, no. 6, pp. 577-586, 2008.

[28] E. G. H. M. van den Heuvel, N. van Schoor, R. T. de Jongh, M. Visser, and P. Lips, "Cross-sectional study on different characteristics of physical activity as determinants of vitamin D status; inadequate in half of the population," European Journal of Clinical Nutrition, vol. 67, no. 4, pp. 360-365, 2013.

[29] D. K. Houston, J. A. Tooze, C. C. Davis et al., "Serum 25hydroxyvitamin D and physical function in older adults: the cardiovascular health study all stars," Journal of the American Geriatrics Society, vol. 59, no. 10, pp. 1793-1801, 2011.

[30] K. Holvik, L. A. Ahmed, S. Forsmo et al., "Low serum levels of 25-hydroxyvitamin D predict hip fracture in the elderly: a NOREPOS study," The Journal of Clinical Endocrinology \& Metabolism, vol. 98, no. 8, pp. 3341-3350, 2013.

[31] 2014, http://www.ecuadorencifras.gob.ec/informacion-censalcantonal/. 


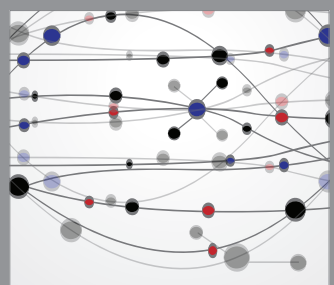

The Scientific World Journal
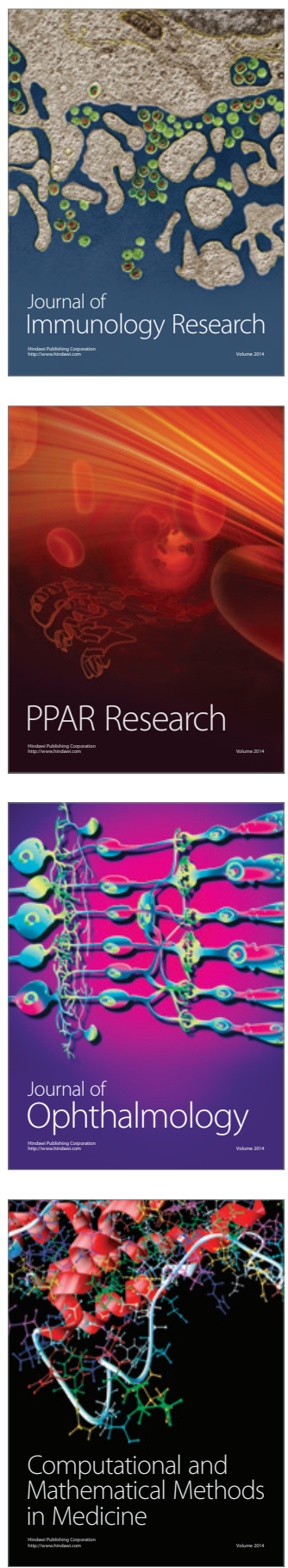

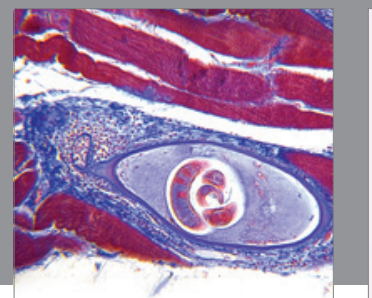

Gastroenterology

Research and Practice
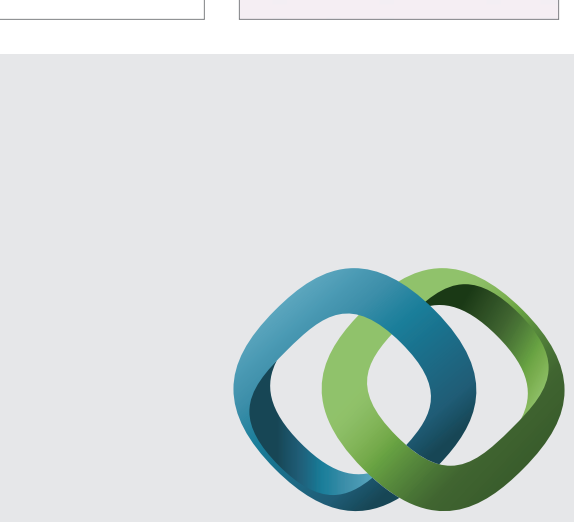

\section{Hindawi}

Submit your manuscripts at

http://www.hindawi.com
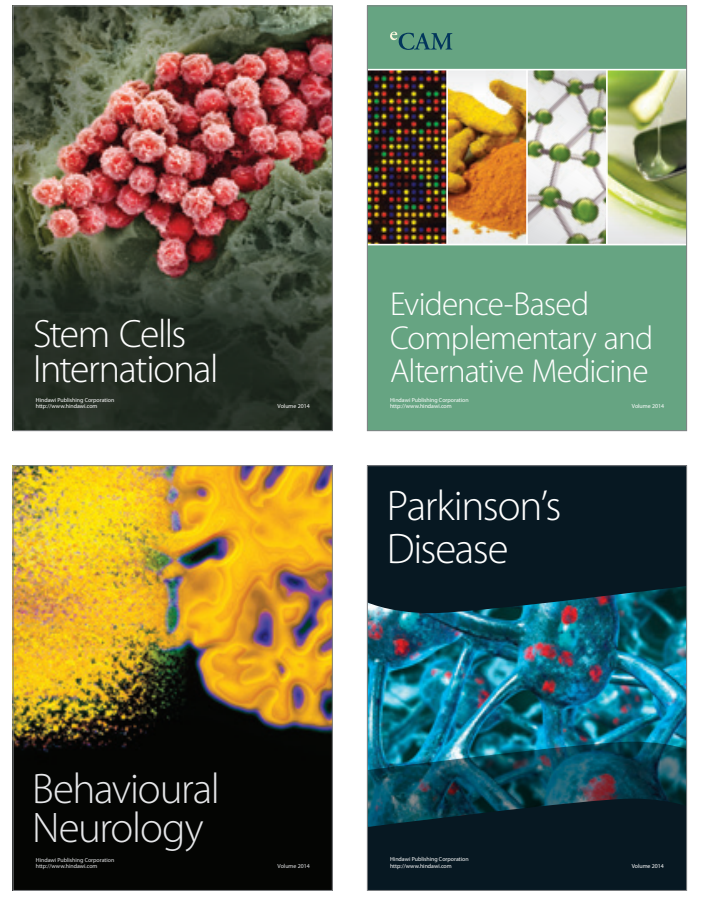
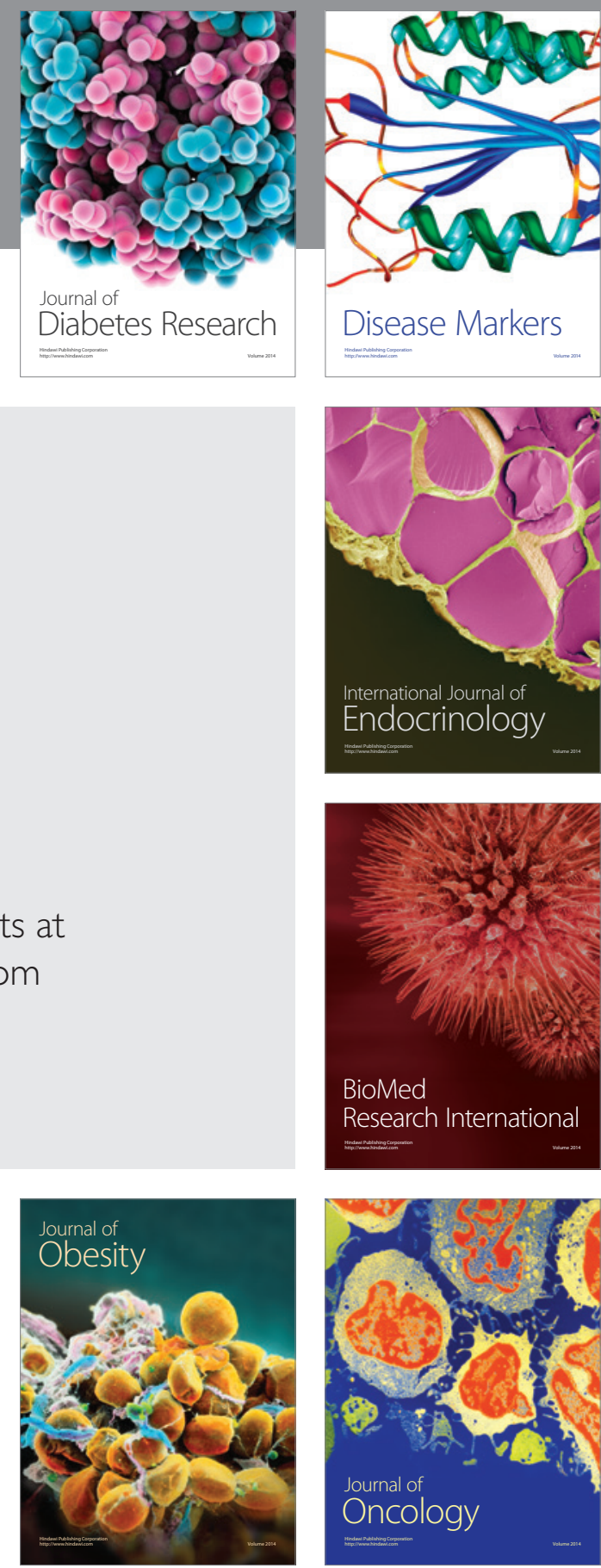

Disease Markers
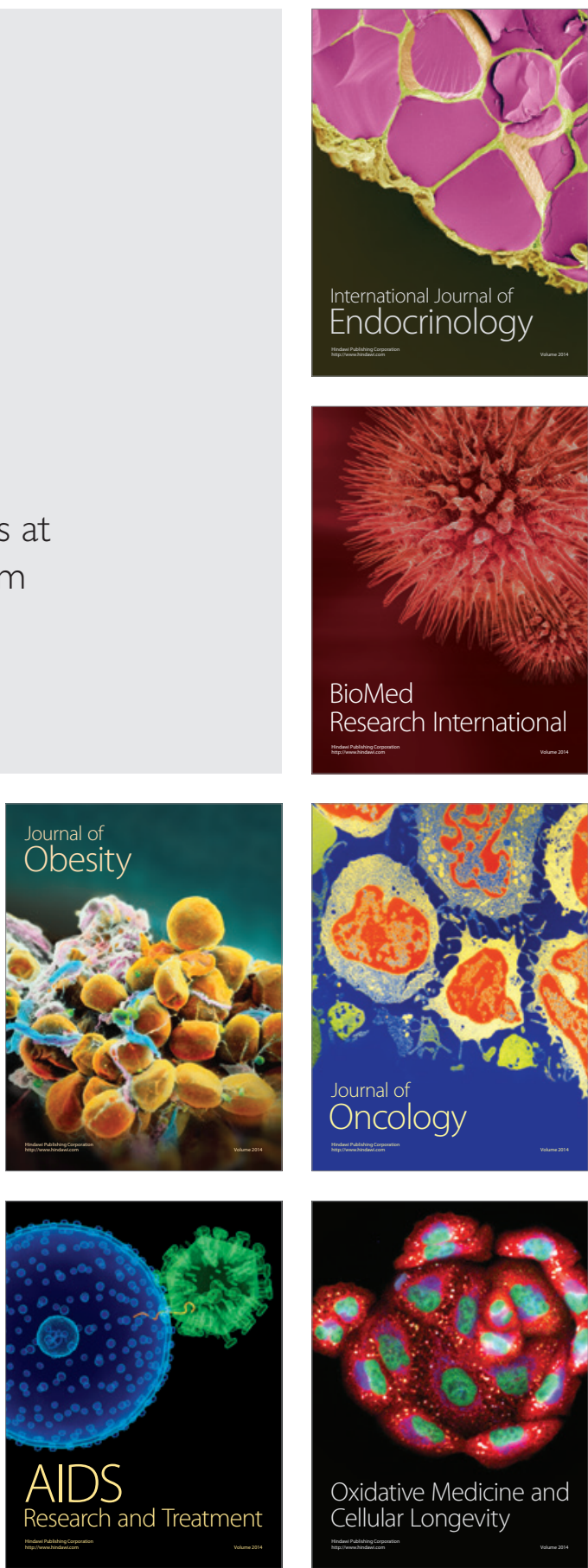